\title{
A Modular, One-Pot, Four-Component Synthesis of
}

\section{Polysubstituted 1,3-Oxazolidines}

David Tejedor, ${ }^{\dagger+}$ Alicia Santos-Expósito, ${ }^{\dagger}$ David González-Cruz, ${ }^{\dagger}$ José Juan Marrero-Tellado ${ }^{\$ \neq}$ and Fernando García-Tellado *

Instituto de Productos Naturales y Agrobiología, Consejo Superior de Investigaciones Científicas, Astrofísico Francisco Sánchez 3, 38206 La Laguna, Tenerife, Islas Canarias, Spain; Instituto Canario de Investigación del Cáncer, and Instituto Universitario de Bioorgánica “Antonio González”, Universidad de La Laguna, Astrofísico Francisco Sánchez 2, 38206 La Laguna, Tenerife, Islas Canarias, Spain.

fgarcia@ipna.csic.es

RECEIVED DATE (to be automatically inserted after your manuscript is accepted if required according to the journal that you are submitting your paper to)

${ }^{\dagger}$ Consejo Superior de Investigaciones Científicas

${ }^{\ddagger}$ Instituto Canario de Investigación del Cáncer (htp://www.icic.es)

$\S$ Universidad de La Laguna

ABSTRACT. A modular, one-pot, two-step, four-component synthesis of polysubstituted 1,3oxzolidines is described. The method comprises two linked domino processes: an organocatalyzed domino reaction of alkyl propiolate and an aliphatic aldehydes and a microwave-assisted amine addition-cyclization domino process. An alternative modular, one-pot, three-step, four-component 
synthesis has also been developed by linking the organocatalyzed domino process to a sequential amine addition/ $\mathrm{Yb}(\mathrm{OTf})_{3}$-catalyzed enamine-cyclization reaction.

KEYWORDS. Coupled-domino processes, organocatalyzed, triethylamine-catalyzed, conjugated acetylide, catalytic-generation, multicomponent, catalytic domino processes, microwave-assisted, silica gel-supported, solvent-free, microwave domestic oven, propargylic alcohol, enol-ether, modular, onepot, diversity-oriented synthesis, nitrogen-containing heterocycles, drug-like heterocycles, privileged structural motives, polysubstituted 1,3-oxazolidines, Ytterbium-catalyzed, enamine-cyclization, tandem addition-cyclization.

The rapid and efficient generation of nitrogen-containing privileged structural motifs is a great challenge in biological, organic and medicinal chemistry. ${ }^{1}$ Domino processes ${ }^{2}$ and multicomponent reactions $(\mathrm{MCR})^{3}$ offer excellent avenues to face these challenges. Notorious examples are the Biginelli, ${ }^{3 \mathrm{f}} \mathrm{Mannich}^{4}$ and $\mathrm{Ügi}^{3 \mathrm{c}-\mathrm{d}}$ reactions. As a part of a wide research program aimed at synthesizing nitrogen-containing drug-like heterocycles by the combined use of domino and $\mathrm{MCR},{ }^{5}$ we became interested in the 1,3-oxazolidine molecule shown in Figure 1. Our interest in these heterocycles lies in their particular chemical topology which combines two biologically relevant structural motifs: an $\alpha, \beta-$ disubstituted 1,2-amino-alcohol ${ }^{6}$ and a latent $\beta$-substituted $\beta$-aminoacid. ${ }^{7,8}$ The masked form of this 1,2amino-alcohol functionality induces a lipophilicity enhancement and consequently, a facilitated drug

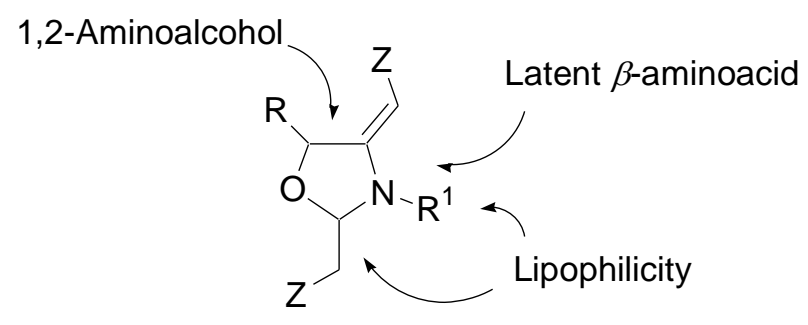

$Z=$ chemically differenced EWG

Figure 1. Fully substituted 1,3-oxazolidines combining an $\alpha, \beta$-disubstituted 1,2-amino-alcohol and a latent $\beta$-substituted $\beta$-aminoacid. 
delivery and a favorable use as prodrugs. ${ }^{9}$ Additionally, the heterocycle is an excellent platform to place pending chemical functionalities in an ordered three-dimensional array. Herein we report on two complementary direct, modular and diversity-oriented approaches to these 1,3-oxazolidines from single and commercially available components (Scheme 1). The first approach comprises a one-pot, three-step, four-component process and combines a trialkylamine-catalyzed synthesis of enol-protected propargylic alcohols $^{5 b, d}$ (domino I) and a thermally-driven amine-addition/Yb(OTf) ${ }_{3}$-catalyzed enaminecyclization ${ }^{10}$ (Scheme 1, steps a, c and d). The second approach involves a metal-free, one-pot, twostep, 4-component process and combines the same trialkylamine-catalyzed domino process (domino I) and a microwave-assisted amine-addition/enamine-cyclization domino process (domino II) (Scheme 1, steps a and $b)$. The first approach was optimized for the synthesis of oxazolidine $\mathbf{3 d}\left(\mathrm{R}={ }^{\mathrm{i}} \mathrm{Pr}, \mathrm{R}^{1}=\mathrm{Bn}\right)$.

SCHEME 1. Two modular, one-pot, 4-component approaches to the synthesis of fully substituted

\section{1,3-oxazolidines 3.}

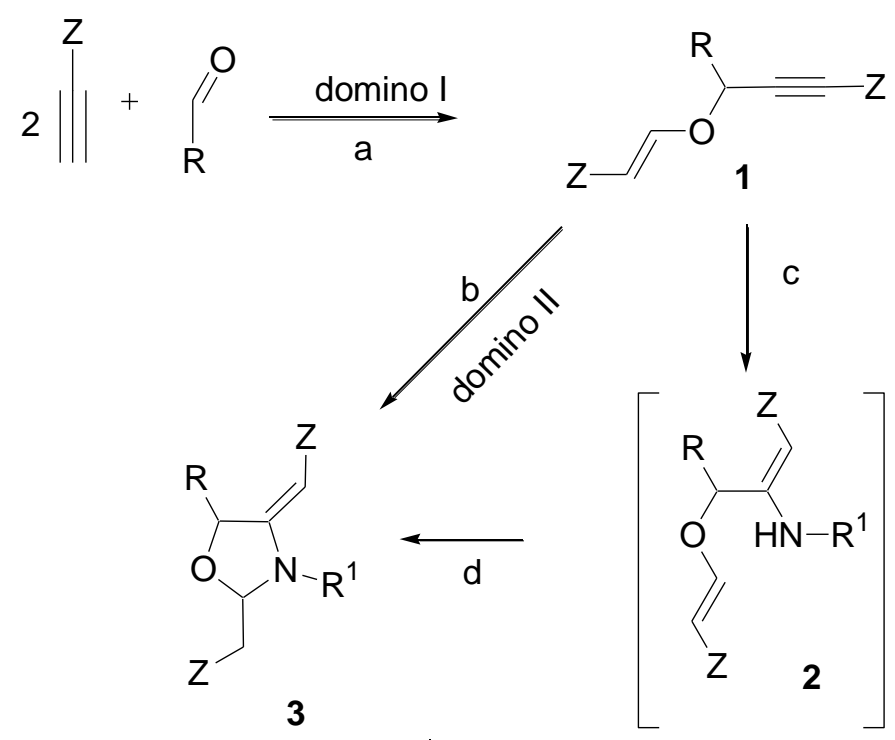

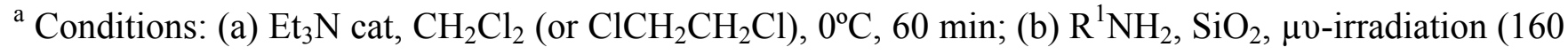
W), 90 min; (c) $\mathrm{R}^{1} \mathrm{NH}_{2}, \mathrm{ClCH}_{2} \mathrm{CH}_{2} \mathrm{Cl}$, reflux, overnight; (d) $\mathrm{Yb}(\mathrm{OTf})_{3}(10 \mathrm{~mol} \%), \mathrm{ClCH}_{2} \mathrm{CH}_{2} \mathrm{Cl}$, reflux, overnight

We pleasantly found that this heterocycle could be obtained in $76 \%$ yield by a sequential conjugated benzylamine addition on the enol-protected propargylic alcohol $\mathbf{1 d}\left(\mathrm{R}={ }^{\mathrm{i}} \mathrm{Pr}\right)\left(\mathrm{CH}_{2} \mathrm{Cl}_{2}\right.$, reflux) followed 
by a $\mathrm{Yb}(\mathrm{OTf})_{3}(10 \mathrm{~mol} \%)$-catalyzed enamine-cyclization. While the amine is nucleophilic enough to give Michael addition on the triple bond, ${ }^{11}$ the cyclization step requires a metallic activation of the $\beta$ oxygenated-acrylate unit to proceed. This chemoselectivity is a very remarkable property of such linear scaffolds and it can be productively used for the controlled generation of skeletal diversity. This tandem set of reactions was applied on other conjugated alkynoates 1 with similar results. Once the heterocycle formation was standardized, we undertook the one-pot version of this 4-MCR (Scheme 1). After some experimentation, we found that the domino synthesis of linear scaffold $\mathbf{1}$ and its sequential transformation into 1,3-oxazolidine 3 could be coupled in a one-pot manner using 1,2-dichloroethane as solvent. Table 1 shows the data for this one-pot 4-MCR. Linear and branched aliphatic aldehydes afforded oxazolidines 3 in good yields (entries 1-4). The procedure is mild enough to allow an isolated

Table 1. Modular, one-pot, 4-component synthesis of 1,3-oxazolidines 3a-j

\begin{tabular}{|c|c|c|c|c|c|c|}
\hline \multirow[b]{2}{*}{ entry } & \multirow[b]{2}{*}{ Z } & \multirow[b]{2}{*}{$\mathrm{R}$} & \multirow[b]{2}{*}{$\mathrm{R}^{1}$} & \multirow[b]{2}{*}{ Prod } & \multicolumn{2}{|c|}{ Yields } \\
\hline & & & & & $\mathrm{Yb}^{3+\mathrm{b}}$ & $\mu v^{\mathrm{a}}$ \\
\hline$\overline{1}$ & $\mathrm{CO}_{2} \mathrm{Me}$ & $\overline{\mathrm{Me}}$ & $\mathrm{Bn}$ & $3 a$ & 71 & 60 \\
\hline 2 & $\mathrm{CO}_{2} \mathrm{Me}$ & Et & $\mathrm{Bn}$ & $3 b$ & 70 & 58 \\
\hline 3 & $\mathrm{CO}_{2} \mathrm{Me}$ & Hex & $\mathrm{Bn}$ & $3 c$ & 55 & 44 \\
\hline 4 & $\mathrm{CO}_{2} \mathrm{Me}$ & 'Pr & $\mathrm{Bn}$ & $3 d$ & 67 & 45 \\
\hline 5 & $\mathrm{CO}_{2} \mathrm{Me}$ & 4- & $\mathrm{Bn}$ & $3 e$ & 54 & 49 \\
\hline & & $\begin{array}{c}\text { Penten } \\
-1-y \mid\end{array}$ & & & & \\
\hline 6 & $\mathrm{CO}_{2} \mathrm{Me}$ & 'Pr & All & $3 f$ & 65 & $36^{c, d}$ \\
\hline 7 & $\mathrm{CO}_{2} \mathrm{Me}$ & 'Pr & $\mathrm{Bu}$ & $3 g$ & 68 & $30^{\mathrm{c}, \mathrm{e}}$ \\
\hline 8 & $\mathrm{CO}_{2} \mathrm{Me}$ & Et & $\mathrm{Ph}$ & $3 \mathrm{~h}$ & NR & $45^{\dagger}$ \\
\hline 9 & $\mathrm{CO}_{2} \mathrm{Me}$ & Et & pMeOPh & $3 \mathbf{i}$ & NR & 55 \\
\hline 10 & $\mathrm{SO}_{2}{ }^{\top}$ olyl $^{g}$ & 'Pr & $\mathrm{Bn}$ & $3 \mathbf{j}$ & 54 & - \\
\hline
\end{tabular}

a (1) Aldehyde (1.1 mmol), alkyl propiolate $(2 \mathrm{mmol}), \mathrm{Et}_{3} \mathrm{~N}(0.5$ mmol), $\mathrm{CH}_{2} \mathrm{Cl}_{2}, 0^{\circ} \mathrm{C}, 60 \mathrm{~min}$. (2) Silica gel $(0.5 \mathrm{~g})$, amine (1.3 mmol). (3) $\mu v$-irradiation $(160 \mathrm{~W}), 90 \mathrm{~min} .{ }^{b}(1)$ The same procedure as before but using dichloromethane as solvent. (2) Amine (1.3 mmol), reflux, overnight. (3) $\mathrm{Yb}(\mathrm{OTf})_{3} \quad(0.10 \mathrm{mmol})$, reflux, overnight. ${ }^{\mathrm{c}}$ Amine $(1.5 \mathrm{mmol}) .{ }^{\mathrm{d}}$ Linear amide $(10 \%) .{ }^{\mathrm{e}}$ Linear amide $(20 \%)$. ${ }^{\mathrm{f}}$ Silica gel $(1 \mathrm{~g})$, amine $(4 \mathrm{mmol}) .{ }^{\mathrm{g}}$ No catalyst was needed to achieve the second domino process. 
double bond on the aldehyde (entry 5). This reactive isolated double bond is a well suited anchor functionality for attachment to other biologically active structures. ${ }^{12}$ In addition, it allows a ready increase in the molecular complexity. Aromatic aldehydes are not substrates for the first domino process and they are not transformed into scaffolds 1. Aromatic amines are not good nucleophiles and they do not give Michael addition to the conjugated triple bond (entries 8-10). On the other hand, benzyl, allyl or alkyl amines launch the second domino reaction to afford oxazolidines $\mathbf{3}$ in good yields (entries 4, 6 and 7). Akynyl sulphones generate the corresponding oxazolidines in an efficient manner without the aid of catalyst (entry 11). With regard to diastereoselectivity, 1,3-oxazolidines $\mathbf{3}$ are obtained as mixtures of syn/anti isomers. ${ }^{13}$ Under these experimental conditions, the kinetic syn isomer equilibrates with the thermodynamic anti isomer affording irresolvable mixtures of both isomers (Diastereomeric ratios are indicated for each product in the supporting information).

Although this first synthetic approach proved quite satisfactory in terms of chemical efficiency and easy processing, we were concerned with the imperative use of a transition-metal catalyst. Thus, we undertook the development of a fully organocatalytic 4-MCR approach. We have recently described that 1,3-oxazolidines 3 rearrange to pyrroles when they are heated or submitted to strong microwave irradiation $\left(\mathrm{SiO}_{2}, 900 \mathrm{~W}, 8 \mathrm{~min}\right){ }^{5 \mathrm{a}}$ After some experimentation, we pleasantly found that mild microwave irradiation (90 min, $160 \mathrm{~W}$ ) of silica gel absorbed mixtures of different scaffolds 1 and benzylamine cleanly afforded 1,3-oxazolidines 3 in good yields (Scheme 1). Under these mild conditions, 1,3-oxazolidines do not rearrange to pyrroles. With these experimental results at hand, we next moved to link this microwave-assisted domino process with the triethylamine-catalyzed synthesis of scaffolds 1 in a one-pot manner. Table 1 shows the data for this new one-pot protocol. In sharp contrast with the $\mathrm{Yb}^{3+}$-catalyzed MCR, aromatic amines are efficient nucleophiles to launch the second domino process (entries 8 and 9). Even aniline, a bad nucleophile, is able to produce the corresponding 1,3-oxazolidine (entry 8), although with low atom efficiency: 4 equivalents of the amine are required to complete the reaction. Volatile amines have to be used in excess to preclude material waste during the silica gel absorption process. In these cases, the direct 1,2 addition of the amine on the ester function 
competes with the 1,4-addition on the triple bond, reducing the overall yield of the 1,3-oxazolidines (entries 6 and 7). With regard to the aldehydes, both linear and branched ones are efficiently transformed into 1,3-oxazolidines (entries 1-5). A reactive isolated double bond on the aldehyde chain is tolerated (entry 5). Unlike the ytterbium-catalyzed MCR, alkynyl sulphones are not suitable substrates for this microwave-assisted domino process. As expected, the less reactive $\mathrm{N}$-aromatic substituted oxazolidines are obtained mainly as the syn isomer (kinetic product) in contrast with the anti-preference of the Naliphatic derivatives.

Overall, this metal-free, one-pot, two-step, organocatalyzed 4-MCR builds up one carbon-carbon bond, one carbon-oxygen bond, two carbon-nitrogen bonds and a ring in a selective and efficient manner. The protocol is modular and utilizes simple and commercially available reagents. In addition, the reaction times are short (less than $3 \mathrm{~h}$ ) and the processing is extremely bench-friendly and environmental-considerate: the first domino process does not require special care with reagents nor solvents; the second one is a solvent-free process. Once the first domino process is completed, silica gel and the primary amine are added to the reaction flask and the mixture is concentrated to dryness. The flask containing the solid mixture is placed in a domestic microwave oven and irradiated at $160 \mathrm{~W}$ for 90 min. Filtration and flash chromatography afford pure 1,3-oxazolidines 3.

These fully substituted 1,3-oxazolidines are very well suited molecular scaffolds for library synthesis of nitrogen-containing privileged structural motifs such as tetrasubstituted pyrroles, ${ }^{10 a} \gamma$-hydroxy- $\beta$ amino acids, 4-amino-furanones, etc. These transformations are being developed in our lab and they will be reported in due course.

In summary, we have described a novel modular, one-pot, two-step, four-component synthesis of fully substituted 1,3-oxazolidines 3 from simple and commercially available starting materials. The method comprises two linked domino processes: an organocatalyzed domino reaction of alkyl propiolate and an aliphatic aldehyde and a microwave-assisted amine addition-cyclization domino process. An alternative modular, one-pot, three-step, four-component synthesis has also been developed by linking the organocatalyzed domino process to a sequential amine addition/Yb(OTf $)_{3}$-catalyzed cyclization. Both 
methods complement each other offering a wide scope of commercially available primary amines, aliphatic aldehydes and alkynoates for the generation of diversity-oriented molecular collections. Bioactivity assays of these heterocyclic compounds are in progress and will be reported elsewhere in due course.

\section{Experimental Section.}

\section{One-pot, two-step, 4-MCR synthesis of 1,3-oxazolidines 3a (representative example): Methyl} propiolate $(2.00 \mathrm{mmol})$ and ethanal $(1.1 \mathrm{mmol})$ were dissolved in $10 \mathrm{~mL}$ of $\mathrm{CH}_{2} \mathrm{Cl}_{2}$. After the mixture was cooled to $0^{\circ} \mathrm{C}$, triethylamine $(0.5 \mathrm{mmol})$ was added and the reaction mixture was allowed to stir for 60 minutes. The solvent and excess reagents were then removed under reduced pressure. The resulting mixture and benzylamine $(1.3 \mathrm{mmol})$ were absorbed on silica gel $(0.5 \mathrm{~g})$ and it was subjected to microwave-irradiation for $90 \mathrm{~min}$ at $160 \mathrm{~W}$. Extraction of the products with ethyl acetate was followed by isolation of the 1,3-oxazolidine 3a (syn/anti: 40/60) by flash column chromatography (silica gel, nhexane/EtOAc 90/10) (60 \%). ${ }^{1} \mathrm{H} \mathrm{NMR}\left(\mathrm{CDCl}_{3}, 500 \mathrm{MHz}\right)$ : syn $\delta 1.47$ (d, 3H, $\left.J=6.4 \mathrm{~Hz}\right), 2.53$ (dd, $1 \mathrm{H}, J=15.5,6.4 \mathrm{~Hz}), 2.66(\mathrm{dd}, 1 \mathrm{H}, J=15.5,3.7 \mathrm{~Hz}), 3.59(\mathrm{~s}, 3 \mathrm{H}), 3.62(\mathrm{~s}, 3 \mathrm{H}), 4.31(\mathrm{~d}, 1 \mathrm{H}, J=16.7$ Hz), $4.44(\mathrm{~d}, 1 \mathrm{H}, J=16.7 \mathrm{~Hz}), 4.61(\mathrm{~d}, 1 \mathrm{H}, J=1.1 \mathrm{~Hz}), 5.48(\mathrm{ddd}, 1 \mathrm{H}, J=6.4,3.7,1.3 \mathrm{~Hz}), 5.68(\mathrm{qt}$, $1 \mathrm{H}, J=6.4,1.2 \mathrm{~Hz}), 7.09-7.18(\mathrm{~m}, 2 \mathrm{H}), 7.27-7.34(\mathrm{~m}, 3 \mathrm{H})$. anti $\delta 1.60(\mathrm{~d}, 3 \mathrm{H}, J=6.4 \mathrm{~Hz}), 2.58(\mathrm{dd}$, $1 \mathrm{H}, J=15.4,7.2 \mathrm{~Hz}), 2.67$ (dd, 1H, $J=15.4,4.0 \mathrm{~Hz}$ ), 3.58 (s, 3H), 3.60 (s, 3H), 4.33 (d, 1H, $J=16.7$ $\mathrm{Hz}), 4.41(\mathrm{~d}, 1 \mathrm{H}, J=16.7 \mathrm{~Hz}), 4.59(\mathrm{~d}, 1 \mathrm{H}, J=1.4 \mathrm{~Hz}), 5.43(\mathrm{dd}, 1 \mathrm{H}, J=7.3,4.0 \mathrm{~Hz}), 5.63(\mathrm{qd}, 1 \mathrm{H}, J=$ 6.4, $1.3 \mathrm{~Hz}), 7.09-7.18(\mathrm{~m}, 2 \mathrm{H}), 7.27-7.34(\mathrm{~m}, 3 \mathrm{H}) .{ }^{13} \mathrm{C} \mathrm{NMR}\left(\mathrm{CDCl}_{3}, 125 \mathrm{MHz}\right): \mathbf{s y n} \delta 18.6,39.5$, $46.9,50.3,51.8,78.4,78.8,88.7,126.6,127.7,129.0,135.0,163.4,168.3,169.5$. anti $\delta 22.1,42.4$, 47.6, 50.3, 51.8, 78.5, 79.6, 91.5, 126.4, 127.8, 128.9, 135.3, 163.4, 168.1, 169.7. IR $\left(\mathrm{CHCl}_{3}, \mathrm{~cm}^{-1}\right)$ 3019.4, 2953.3, 1732.0, 1690.4, 1611.8, 1147.9. Anal. Calcd. for $\mathrm{C}_{17} \mathrm{H}_{21} \mathrm{NO}_{5}: \mathrm{C}, 63.94 ; \mathrm{H}, 6.63 ; \mathrm{N}$, 4.39. Found: C, 63.78; H, 6.61; N, 4.48. MS, m/z (relative intensities) 319 (M+1 , 38), 246 (29), 217 (13), $186(11), 158(13), 129(10), 91(100)$. 


\section{One-pot, three-step, 4-MCR synthesis of 1,3-oxazolidines 3b (representative example): Methyl}

propiolate $(2.00 \mathrm{mmol})$ and propanal $(1.1 \mathrm{mmol})$ were dissolved in $10 \mathrm{~mL}$ of $\mathrm{ClCH}_{2} \mathrm{CH}_{2} \mathrm{Cl}$. After the mixture was cooled to $0^{\circ} \mathrm{C}$, triethylamine $(0.5 \mathrm{mmol})$ was added and the reaction mixture was allowed to stir for 60 minutes. Benzylamine $(1.3 \mathrm{mmol})$ was added and the resulting mixture was refluxed overnight. $\mathrm{Yb}(\mathrm{OTf})_{3}(10 \mathrm{mmol} \%)$ was added and the reaction mixture was again refluxed overnight. After cooling, the mixture was poured on an aqueous saturated solution of sodium bicarbonate and decanted off. The aqueous layer further extracted with $\mathrm{CH}_{2} \mathrm{Cl}_{2}$ (x2) and the organic phases were combined, washed with brine, dried over sodium sulphate and filtered. Flash chromatography of the resulting residue afforded 1,3-oxazolidine 3b (syn/anti: 40/60) (silica gel, n-hexane/EtOAc 90/10) (70 \%). ${ }^{1} \mathrm{H} \mathrm{NMR}\left(\mathrm{CDCl}_{3}, 400 \mathrm{MHz}\right): \delta$ syn $\delta 0.97(\mathrm{~d}, 3 \mathrm{H}, J=7.5 \mathrm{~Hz}), 1.62(\mathrm{~m}, 1 \mathrm{H}), 1.89$ (sextet of doublets, $1 \mathrm{H}, J=7.5,3.0 \mathrm{~Hz}), 2.50(\mathrm{dd}, 1 \mathrm{H}, J=15.6,6.1 \mathrm{~Hz}), 2.59(\mathrm{dd}, 1 \mathrm{H}, J=15.6,4.0 \mathrm{~Hz}), 3.53(\mathrm{~s}$, $3 \mathrm{H}), 3.56(\mathrm{~s}, 3 \mathrm{H}), 4.25(\mathrm{~d}, 1 \mathrm{H}, J=16.4 \mathrm{~Hz}), 4.38(\mathrm{~d}, 1 \mathrm{H}, J=16.4 \mathrm{~Hz}), 4.57(\mathrm{~d}, 1 \mathrm{H}, J=1.0 \mathrm{~Hz}), 5.39(\mathrm{~m}$, 1H), $5.43(\mathrm{~m}, 1 \mathrm{H}), 7.10(\mathrm{td}, 2 \mathrm{H}, J=8.0,1.2 \mathrm{~Hz}), 7.34(\mathrm{~m}, 1 \mathrm{H}), 7.44(\mathrm{~m}, 2 \mathrm{H})$. anti $1.01(\mathrm{t}, 3 \mathrm{H}, J=7.5$ $\mathrm{Hz}), 1.62(\mathrm{~m}, 1 \mathrm{H}), 2.12$ (sextet of doublets, $1 \mathrm{H}, J=7.5,3 \mathrm{~Hz}), 2.52(\mathrm{dd}, 1 \mathrm{H}, J=15.3,7.4 \mathrm{~Hz}), 2.60$ (dd, $1 \mathrm{H}, J=15.3,4.0 \mathrm{~Hz}), 3.52(\mathrm{~s}, 3 \mathrm{H}), 3.55(\mathrm{~s}, 3 \mathrm{H}), 4.27(\mathrm{~d}, 1 \mathrm{H}, J=16.4 \mathrm{~Hz}), 4.33(\mathrm{~d}, 1 \mathrm{H}, J=16.4 \mathrm{~Hz})$, $4.54(\mathrm{~d}, 1 \mathrm{H}, J=1.3 \mathrm{~Hz}), 5.39(\mathrm{~m}, 1 \mathrm{H}), 5.43(\mathrm{~m}, 1 \mathrm{H}), 7.10(\mathrm{td}, 2 \mathrm{H}, J=8.0,1.2 \mathrm{~Hz}), 7.34(\mathrm{~m}, 1 \mathrm{H}), 7.44$ (m, 2H). ${ }^{13} \mathrm{C}$ NMR (CDCl3, $\left.100 \mathrm{MHz}\right)$ : syn $\delta 10.2,25.9,39.6,47.0,51.8,78.4,83.8,89.2,126.4,126.7$, $127.7,128.9,135.3,162.4,168.4,169.5$. anti $\delta 10.0,28.4,42.1,47.8,50.3,78.7,84.5,91.6,126.4$, 126.7, 127.7, 128.9, 135.0, 162.6, 168.2, 169.7. IR $\left(\mathrm{CHCl}_{3}, \mathrm{~cm}^{-1}\right)$ 3018.1, 2951.5, 1736.2, 1688.1, 1607.6, 1435.6, 1385.3, 1147.9. Anal. Calcd. for $\mathrm{C}_{18} \mathrm{H}_{23} \mathrm{NO}_{5}$ : C, 64.85; H, 6.95; N, 4.20. Found: C, 64.98; H, 6.82; N, 4.39. MS, m/z (relative intensities) 333 (M+, 5.9), 172 (5.3), 91 (100), 65 (7.9).

Acknowledgment. This research was supported by the Spanish Ministerio de Educación y Ciencia (PPQ2002-04361-C04-03). D.G.C. thanks the Spanish Ministerio de Educación y Ciencia for a FPI grant. F.G.T. and D.T. thank the Instituto Canario de Investigación del Cáncer for financial support 
(ICIC-PI. n 07/2004; ISCiii, RTICCC C03/10). F.G.T. thanks Dr. Pedro de Armas and Professor Victor

S. Martin for helpful discussions about this manuscript.

Supporting Information Available: Spectroscopic and analytical data for compounds 3c-j (PDF).

This material is available free of charge via internet at htpp://pubs.acs.org.

\section{REFERENCES.}

${ }^{1}$ (a) Hulme, C.; Gore, V. Curr. Med. Chem. 2003, 10, 51-80. (b) Burke, M. D.; Berger, E. M.; Schreiber, S. Science 2003, 302, 613-618. (c) Zhu, J. Eur. J. Org. Chem. 2003, 1133-1144. (d) Wess, G.; Urmann, M.; Sickenberger, B. Angew. Chem., Int. Ed. 2001, 40, 3341-3350. (e) Arya, P.; Chou, D. T. H.; Baek, M. G. Angew. Chem., Int. Ed. 2001, 40, 339-346. (f) Drews, J. Science 2000, 287, 19601964. (g) Weber, L. Curr. Opin. Chem. Biol. 2000, 4, 295-302.

${ }^{2}$ (a) Tietze, L. F.; Haunert, F. in Stimulating Concepts in Chemistry; Shibasaki, M.; Stoddart, J. F.; Vögtle, F., Eds.; Wiley-VCH: Weinheim, 2000, pp 39-64. (b) Tietze, L. F. Chem. Rev. 1996, 96, 115136.

${ }^{3}$ (a) von Wangelin, A. J.; Neumann, H.; Gördes, D.; Klaus, S.; Strübing, D.; Beller, M. Chem.-Eur. J. 2003, 9, 4286-4294. (b) Orru, R. V. A. ; Greef, M. Synthesis 2003, 10, 1471-1499. (c)Ugi, I. Pure Appl. Chem. 2001, 73, 187-191. (d) Dömling, A.; Ugi, I. Angew. Chem. Int. Ed. 2000, 39, 3168-3210. (e) Bienaymé, H.; Hulme, C.; Oddon, G.; Schmidt, P. Chem. -Eur. J. 2000, 6, 3321-3329. (f) Kappe, C. O. Acc. Chem. Res. 2000, 33, 879-888. (g) Filippini, M. H.; Rodriguez, J. Chem. Rev. 1999, 99, 27-76. (h) Weber, L.; Illgen, K.; Almstetter, M. Synlett 1999, 366-374.

${ }^{4}$ Arend, M.; Westermann, B.; Risch, N. Angew. Chem. Int. Ed. 1998, 37, 1044-1070.

5 (a) Tejedor, D.; González-Cruz, D.; García-Tellado, F.; Marrero-Tellado, López Rodriguez, M.. J. Am. Chem. Soc. 2004, 126, 8390-8391. (b) Tejedor, D.; García-Tellado, F.; Marrero-Tellado, J. J.; de Armas, P. Chem.-Eur. J. 2003, 9, 3122-3131. (c) Tejedor Aragón, D.; López, G. V.; García-Tellado, F.; Marrero-Tellado, J. J.; de Armas, P.; Terrero, D. J. Org. Chem. 2003, 68, 3363-3365. (d) de Armas, P.; 
García-Tellado, F.; Marrero-Tellado, J. J.; Tejedor, D.; Maestro, M. A.; González-Platas, J. Org. Lett. 2001, 3, 1905-1908.

${ }^{6}$ (a) For an excellent review on synthesis of vicinal amino-alcohols including many naturally occurring and biologically relevant compounds, see: Bergmeier, S. C. Tetrahedron 2000, 56, 2561-2576; (b) for a review on synthesis and biological activities of long chain 2-amino alcohols, see: ConstantinouKokotou, V. Lett. Pept. Sci. 2003, 9, 143-152. For other examples of biologically active amino alcohols, see: (c) Golebiowski, A.; Jurczac, J. Synlett, 1993, 241-245. (d) Yokomatsu, T.; Yuasa, Y.; Shibuya, S. Heterocycles 1992, 33, 1051-1078. (e) Ohfune, Y. Acc. Chem. Res. 1992, 25, 360-366. (f) Reetz, M. Angew. Chem. Int. Ed. Engl. 1991, 30, 1531-1545.

${ }^{7}$ (a) For a recent review on $\beta$-substituted $\beta$-aminoacids synthesis, see: Liu, M.; Sibi, M. P. Tetrahedron 2002, 58, 7991-8035. For some examples of naturally occurring $\beta$-substituted $\beta$-aminoacids, see: (b) Luesch, H.; Williams, P. G.; Yoshida, W. Y.; Moore, R. E.; Paul, V. J. J. Nat. Prod. 2002, 65, 9961000. (c) Pettit, G. R.; Kamano, Y.; Kizu, H.; Dufresne, C.; Herald, C. L.; Bontems, R.; Schmidt, J. M.; Boettner, F. E.; Nieman, R. A. Heterocycles 1989, 28, 553-558. (d) Mynderse, J. S.; Hunt, A. H.; Moore,R. E. J. Nat. Prod. 1988, 51, 1299.

${ }^{8}$ For recent reviews on $\beta$-amino acids applications, see: (a) Steer, D. L.; Lew, R.A.; Perlmutter, P.; Smith, A. I.; Aguilar, M. I. Curr. Med. Chem. 2002, 9, 811-822. (b) Hill, D. J.; Mio, M. J.; Prince, R. B.; Hughes, T. S.; Moore, J. S. Chem. Rev. 2001, 101, 3893-4011. (c) Cheng, R. P.; Gellman, S. H.; DeGrado, W. F. Chem. Rev. 2001, 101, 3219-3232. (e) Gademann, K.; Hintermann, T.; Schreiber, J. V. Curr. Med. Chem. 1999, 6, 905-925.

${ }^{9}$ (a) Moloney, G. P.; Craik, D. J.; Iskander, M. N.; Nero, T. L. J. Chem. Soc., Perkin Trans. 2 1998, 199-206. (b) Walker, R. B.; Wood, D. M.; Akmal, M. M.; Sharks, E. Gen. Pharmacol. 1992, 23, 72932. (c) Walker, R. B.; Wood, D. M.; Akmal, M. M. Life Sci. 1990, 47, 595-600. (d) Schoenwald, R. D.; 
Chien, D. S. Biopharm. Drug Dispos. 1988, 9, 527-38. (e) Young-Harvey, J. A.; Rae, I. D.; Pitman, I. H. Int. J. Pharm. 1986, 30, 151-160. (f) Johansen, M.; Bundgaard, H. J. Pharm. Sci. 1983, 72, 1294-1298.

${ }^{10}$ Mastsubara, S.; Yoshioka, M.; Utimoto, K. Chem. Lett. 1994, 827-830.

${ }^{11}$ Jung, M. E. In Comprehensive Organic Synthesis; Trost, B. M., Fleming, I., Semmelhack, M. F., Eds.; Pergamon Press: Oxford, 1991, Vol.4, Chapter 1, pp 47-53.

${ }^{12}$ For an example, see: Brohm, D.; Metzger, S.; Bhargava, A.; Müller, O.; Lieb, F.; Waldmann, H. Angew. Chem. Int. Ed. 2002, 41, 307-311.

${ }^{13}$ For an interesting discussion on diastereoselectivity in the synthesis of 1,3-oxazolidines, see: Agami, C.; Couty, F. Eur. J. Org. Chem. 2004, 677-685 and references cited therein.

TOC

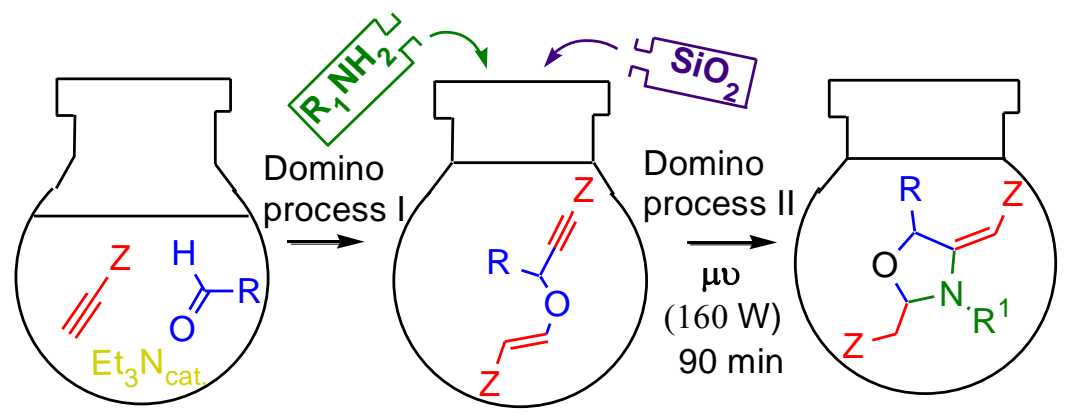

